\title{
Ukraine: Der er sket noget afgørende
}

Af Tage Baumann

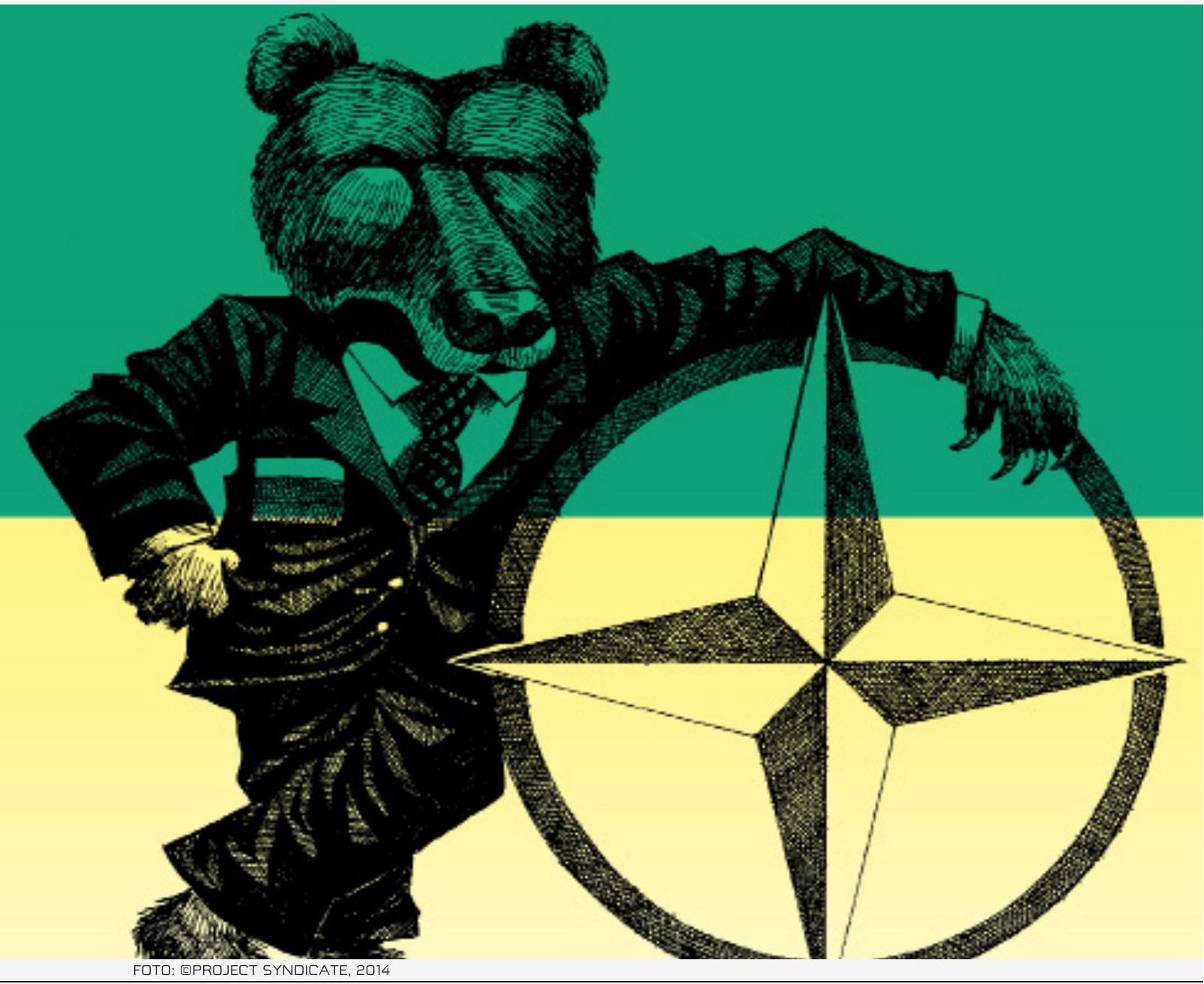


NATO-topmødet i Newport i Wales i september blev på forhånd beskrevet som skelsættende fordi det skulle afstikke kursen for tiden efter Afghanistan. I stedet blev dagsordenen sat af Ukraine, og NATOs umiddelbare udfordring er at vise, at alliancen har generobret initiativet og sætter sin egen dagsorden.

Den 24. juli deltog den amerikanske forsvarschef, general Martin Dempsey, i dette års Aspen Security Forum i Aspen, Colorado.

Ifølge Dempsey skaber Ruslands måde at agere på i krisen i og om Ukraine en helt ny sikkerhedspolitisk situation i Europa. Det handler om Europas forhold til Rusland, og det handler om USA's forhold til Rusland, og det første spørgsmål om, hvad det så betyder, skal stilles i NATO. NATOtopmødet i september i Newport, Wales vil være et godt sted at begynde, for det er den vestlige alliance, der nu skal definere, hvad den nye situation kræver af alliancens evner og selvopfattelse.

Ruslands anneksion af Krim-halvøen er bekymrende, og nedskydningen af det malaysiske rutefly $\mathrm{MH} 17$ og tabet af 298 uskyldige menneskeliv er meget bekymrende. Men det, der fik general Dempsey til at slå alarm, er informationer, som amerikanerne siger, at de har, om at der er skudt artilleri-ild fra russisk område ind over grænsen til Ukraine som støtte til de militært trængte pro-russiske oprørsstyrker i den østlige del af landet.

Det viser, siger Dempsey, at Moskva er parat til at bruge militær magt hen over en landegrænse i Europa for at nå sine politiske mål. Det er det han ser som en sikkerhedspolitisk gamechanger, for nu at bruge et af tidens modeord: noget der ændrer spillet totalt.

Dempsey er USA's øverste soldat, og USA er alliancens ubestridte leder. Hans advarsel om nye sikkerhedspolitiske tider i Europa gør nok mere indtryk hos politiske beslutningstagere end lignende advarsler, der har lydt i længere tid fra sikkerhedspolitiske forskere.

\section{Stoltenbergs udfordring}

Her i Norden er det danske og svenske forskere, der har meldt sig på banen, mens norske og finske går forbavsende stille med dørene i denne sag.

Alligevel bliver Ukraine-krisen mindst en nordmands hovedpine: Jens Stoltenberg, som fra NATO-topmødet i begyndelsen af september tager over fra danske Anders Fogh Rasmussen som alliancens generalsekretær. Og altså som den, der skal lede alliancens arbejde med at formulere en ny strategisk fortælling til en ny sikkerhedspolitisk udfordring.

Let bliver det ikke. For selvom de 28 medlemslande er enige i kritikken af den rolle, Rusland spiller og har spillet i Ukraine-krisens forløb, så er der tydelige forskelle i bedømmelsen af, hvad det så betyder for fremtiden, og hvordan der skal svares på den russiske udfordring. Det har meget at gøre med denne konflikts specifikke karakter og med de mangearterede nationale interesser, der er i spil - også på vestlig side. Stikord er 'mangfoldige trusler' og 'hybridkrig', men mere om det nedenfor.

Det første spørgsmål er, om general Dempsey har ret i, at vi står med en helt ny sikkerhedspolitisk situation i Europa og i forholdet mellem USA og Rusland i lyset af de erfaringer, vi allerede har med konflikten i og om Ukraine.

Tage Baumann er sikkerhedspolitisk medarbejder på DR-programmet Orientering. 
Kortest og mest klart formulerer de svenske forsvarspolitikere det i den forsvarsbetænkning Försvaret av Sverige - starkere försvar för en osäker tid, som kom den 15 maj som optakt til en ny svenske forsvarsordning. Her hedder det, at de to konklusioner, der må drages af erfaringerne med Ruslands opførsel i krisen, og som gør, at det sikkerhedspolitiske billede i Europa er ændret grundlæggende, er:

- at krisen viser noget nyt om Ruslands, eller i hvert fald om præsident Vladimir Putins hensigter, og

- at Ruslands overtagelse og indlemmelse af Krim-halvøen i Rusland bekræfter antagelsen om, at Rusland har krigsevner, som man hidtil nærmest havde betragtet med nogen skepsis, men som man nu er nødt til at tage med i det sikkerhedspolitiske regnestykke i Europa.

Denne politiske analyse følges op af rapporten En brat opvågnen med undertitlen virkningerne af den russiske aggression mod Ukraine, som et hold forskere fra Totalförsvarets Forskningsinstitution, FOI, med Niklas Granholm i spidsen fremlagde for få uger siden. FOI kan sammelignes med Forsvarsakademiet i Danmark.

Efter en grundig analyse af følgerne af Ukraine-krisen og den russiske måde at agere på konkluderer forskerne, at det, der er kendt om Ruslands evner og Ruslands hensigter, og det, der er afsløret om EU og NATOs manglende evner til at finde et effektivt svar over for Moskva, gør det umuligt at søge efter løsninger der vil genoprette status quo ante - situationen som den var før krisen.

\section{Den danske vinkel}

Noget afgørende er sket, noget afgørende nyt, konkluderer også det forskerhold fra Center for Militære Studier, CMS, på Københavns Universitet, som nøjagtig samtidigt med svenskerne fremlagde rapporten Ukrainekrisen og forandringen af dansk forsvars- og sikkerhedspolitik.
Den danske rapport har et andet fokus end den svenske FOI-rapport. Det skyldes, at svenskerne som nævnt den 15. maj fremlagde en forsvarspolitisk betænkning med fokus på svensk forsvar, og derfor kunne forskerholdet fra FOI fokusere på de større sikkerhedspolitiske forandringer som følge af Ukraine-krisen. CMSrapporten kom i stand, både fordi forskerne på CMS selv mente, at det var oplagt at gennemføre sådan en analyse, og fordi regeringen og partierne bag det danske forsvarsforlig, som har ret til at bestille analyser af CMS, syntes det var en god ide. Analysen skulle blot tage sigte på at belyse følgerne for dansk forsvarspolitik, og som den fulde titel på CMS-rapporten viser, blev det netop opgaven.

For at nå frem til anbefalinger til en ny dansk forsvarspolitik måtte forskerholdet på Københavns Universitet naturligvis analysere de større, europæiske og globale, sikkerhedspolitiske betingelser, sådan som de ser ud efter den militære og sikkerhedspolitiske aktualisering af krisen i og om Ukraine. Og de københavnske forskere kom, som de svenske, til det resultat, at noget afgørende er sket, noget afgørende er forandret.

Lignende synspunkter har også professor Steen Rynning fra Center for War Studies på Syddansk Universitet givet udtryk for i kronikker og interviews, og forsker Lars Bangert Struwe fra CMS, som var talsmand for gruppen, da rapporten blev offentliggjort, sagde ved den lejlighed, at en stor del af de europæiske forskere, som de havde været i kontakt med, var enige: Det er et afgørende øjeblik i europæisk sikkerhedspolitik, vi har været vidne til siden februar. Hvor afgørende er svært at bedømme, mens krisen stadig udvikler sig.

\section{Ny russisk dagsorden}

Spørgsmålet er, om den situation, vi står i i Europa lige nu, kunne være undgået, 
Ruslands overtagelse og indlemmelse af Krim-halvøen i Rusland bekræfter antagelsen om, at Rusland har krigsevner, som man hidtil nærmest havde betragtet med nogen skepsis, men som man nu er nødt til at tage med i det sikkerhedspolitiske regnestykke i Europa.

hvis Vesten havde reageret anderledes og i tide. Eller om en konflikt, som den vi oplever lige nu, under alle omstændigheder, før eller siden, ville være kommet i den eller en anden form.

Så længe det så ud til, at Ruslands ambitioner var at blive en del af det internationale samfund, som USA og Vesten definerer det, er svaret muligvis, at ja, Vesten kunne have handlet anderledes og præget udviklingen $i$ en anden retning.

Men fra det øjeblik, hvor Ruslands ledere opgav at få skabt tilstrækkeligt politisk-diplomatisk manøvrerum for sig selv til at tage plads ved det vestlige bord, er svaret snarere, at konflikten ville komme under en eller anden form under alle omstændigheder.

Først nu, hvor konflikten er der, ser det ud til at gå op for Vesten, at Ruslands projekt er et andet end Vestens. Det er ikke længere et spørgsmål om, hvordan Rusland 'passer ind' i den vestlig-liberale verdensorden. Det afgørende nye er, at Rusland ikke længere abonnerer på den vestlige verdensorden.

Rusland har opgivet det forsøg og søger nye, egne veje. Mest tydeligt i præsident Vladimir Putins forsøg på at opbygge et euro-aisatiske samarbejde som modstykke til det euroatlantiske. Set fra Moskva er EU og USA nu en gang ikke hele verden, selv om den vestlige debat ofte lader som om.

De svenske og danske forskere er enige om, at det her er større end personen Vladimir Putin. Han er måske nok katalysator og drivende kraft i formuleringen af en ny russisk udenrigs- og sikkerhedspolitik, men han er også udtryk for en måde at se verden på, som deles ikke bare af folkene om- kring ham, men af store dele af den russiske befolkning. Ruslands indlemmelse af Krim, måden det skete på og den opfattelse af Ruslands placering i verdensordnen, der ligger bag, er i deres analyse et folkeligt projekt. Putins politik er i denne forbindelse legitimeret af en folkelig opbakning, der ikke vil forsvinde den dag, Vladimir Putin ikke længere er nøgleperson i den russiske politik.

Der var måske et øjeblik, hvor udviklingen kunne være ledt $i$ andre retninger, retninger der havde ført til, at Rusland - ikke uden problemer, men trods alt - kunne finde sin stemme i den vestlige koncert. Historikerne må med tiden afgøre, om den tale, Vladimir Putin holdt på sikkerhedskonferencen i München i 2007, var et brud med Vesten og en tilbagevenden til en koldkrigs-situation, sådan som ikke mindst tilstedeværende amerikanske politikere med senator John McCain i spidsen øjeblikkeligt mente. Eller om talen i virkeligheden var et forsøg på at lokalisere og identificere de områder, hvor et samarbejde var muligt og en fællesnævner kunne findes, og samtidig en beskrivelse af, hvordan verden så ud set fra Moskva.

Som det var, blev Putins tale afvist som krigerisk og aggressiv, og Putins analyse affærdiget som løgn og forsøg på bedrag. Putins grundtese om en unipolær verden med total amerikansk dominans og kravet om, at det var den verdensorden, der burde ændres, blev fejet af bordet af John McCain med bemærkningen om, at det var Rusland der måtte forstå, at verden var multipolær, og at det var Rusland der måtte ændre sin indstilling.

De ansatser, der var i Putins tale til et ligeberettiget samarbejde for eksempel på 
energiområdet, forsvandt i det efterfølgende opgør, der på vestlig side endte i konstateringen af, at Putins Rusland ville genoplive eller måske bare levede videre i den kolde krig.

Præsident Obama forsøgte at ro tilbage til øjeblikket før Putins 2007-tale med sin plan om at genstarte - 'reset' - det amerikansk-russiske forhold. Det forsøg kuldsejlede i februar i år, og det kuldsejlede på Krim. Måske fordi udgangspunktet også for det forsøg var den antagelse, at det var Rusland, der skulle tilpasse sig Vesten og ikke en fælles søgen efter en ny global orden.

\section{På vej mod noget nyt}

Igen høres advarslen om, at vi er på vej ind i en ny kold krig. Men forskerne er enige om, at det ikke er en tilbagevenden til noget kendt, omend uelsket. De er enige om, at her er noget helt nyt på vej: Et Rusland som ikke definerer sig selv i forhold til det euroatlantiske projekt og prøver at blive en del af det, men tværtimod forsøger at definere grænsen - med magt om nødvendigt - mellem det euroatlantiske projekt og det euroasiatiske projekt, Moskva arbejder på.

Ambitionerne er på den måde ikke længere at få indflydelse på eller argumentere mod den euroatlantiske orden, men at afskrive den og vende ambitionerne mod øst og syd og orientere sig i forhold til Kina og Indien og de lande, der af geografisk nødvendighed må gruppere sig omkring de to.

Det giver på lang sigt også økonomisk, især måske energiøkonomisk, mening at orientere sig i retning af de kommende store afsætningsmarkeder for energi og industriproduktion.

I CMS-rapporten sammenfattes konsekvenserne af det, der er sket siden februar, og som Vesten må forholde sig til, i tre punkter.

For det første at Rusland er parat til at bruge væbnet magt i sit nærområde, en erfaring der gør at Vesten må arbejde med et meget kortere strategisk varsel i forhold til
Rusland, end det har været antaget siden den kolde krigs ophør og Sovjetunionens og Warszawapagtens opløsning.

For det andet - og det er det vigtige lige her - det "tilsyneladende endegyldige russiske brud med ideen om et helt og frit Europa, der startede med Helsinki-processen, og blev som realiseret med integrationen af økonomier og samfund efter afslutningen af den kolde krig".

For det tredje at de partnerskabsprojekter, som siden den kolde krigs afslutning har været dét, som både EU og NATO har bygget på, har været utilstrækkelige. Og det tvinger NATO og EU til at gentænke den vestlige strategi.

\section{Hvor går grænsen?}

Det er som sagt punkt to, der er det relevante i denne forbindelse. For hvis det er rigtigt, at Rusland har brudt endegyldigt med hele tankesættet bag Helsinki-processen, hvis kerne i russisk - den gang sovjetisk - optik netop var at legalisere og fastskrive de grænser, der var resultatet af Anden Verdenskrig, og knæsætte det princip, at Europas grænser ikke kan ændres med vold, så har Rusland meldt sig ud af et fælles europæisk projekt. Om ikke andet så ved at demonstrere, at i tilfældet Krim var Rusland meget vel parat til at ændre europæiske grænser med vold. Kun den nærmeste tids udvikling vil vise, om Rusland også er parat til at ændre de østukrainske grænser med militær magt.

Det Vesten ikke kan aflæse af Ukrainekrisen alene er, hvor Rusland selv ser den nye grænse mellem det Europa, Moskva er i færd med helt at vende rygge til, og den nye russiske indflydelsessfære i det nærområde, som Rusland tilsyneladende er ved at bygge op.

Men mistanken må være, at de euroatlantiske og de russiske forestillinger om en sådan grænsedragning ikke er sammenfaldende, og at Rusland i tilfælde af uenighed, som i Ukraine, er parat til at forsøge 
at skabe eller ændre kendsgerninger på jorden med våbenmagt. Direkte eller indirekte som det er sket de seneste måneder.

Det må især bekymre NATO's nye 'frontlinje-stater' - også uden at købe tesen om en ny kold krig. Det er to typer af NATOlande, det handler om: de tidligere medlemsstater i Warszawapagten, som nu deler grænse med Rusland, og de tidligere sovjetrepublikker som igen er suveræne stater og alliancemedlemmer. Polen hører til de første, de baltiske lande til de sidste. Antagelsen har hele tiden været, at Warszawapagtstater, der blev medlem af NATO, var en mindre provokation i russiske øjne end tidligere sovjetrepublikker, der blev optaget $\mathrm{i}$ alliancen. Derfor de hårde russiske reaktioner på debatten om Georgiens og Ukraines mulige medlemskab. Derfor den russisk-georgiske krig i 2008 og derfor den russiske aggression over for Ukraine nu.

\section{Er Rusland en reel trussel?}

Den konstatering må nødvendigvis forurolige Polen og andre NATO-lande med grænse til Rusland og i helt særlig grad forurolige de baltiske stater, som samtidig er tidligere sovjetrepublikker. Kun erfaringen vil vise om det, Rusland er i gang med lige nu, er at definere Europas østgrænse forstået som det europæiske projekts østgrænse. Eller om det er et forsøg på med militær intimidering at holde Ukraine og Georgien - mest det første og største - som neutrale stødpudestater mellem EU/NATO på den ene og Rusland og det nye euro-asiatiske russiske projekt på den anden side. Eller om det er begge dele.

Svaret på det vil også være svaret på, hvor reel og akut en trussel Rusland nu er for de baltiske stater, for Polen og for den sikkerhedspolitiske balance i Østersøen - enten direkte eller indirekte. Vanskeligheden består i, at fordi det ikke er muligt med nogen sikkerhed at afgøre, hvilket svar der er det rigtige, så må EU, NATO og de enkelte medlemslande i Ruslands nærområde indstille sig på hver af de tre muligheder.
Det Rusland, som den transatlantiske alliance står overfor i dag, er ikke hverken det tidligere Sovjetunionen eller det afmægtige Rusland, der var tilbage, efter at Sovjetunionen faldt fra hinanden, og heller ikke det Rusland, Vladimir Putin repræsenterede, da han holdt sin tale i München i 2007.

Økonomisk er Rusland kommet på fode, godt hjulpet af dramatisk stigende energipriser på det verdensmarked, som Rusland er en af storleverandørerne til. Og militært synes de reformer og moderniseringer, der blev sat i gang omkring 2008, at virke i betydeligt omfang. Resultatet er et russisk militær, der ser ud til at have betydeligt større evner end hidtil antaget, og moderniseringen er langt fra færdig endnu. Dertil kommer en særlig russisk anstrengelse for at forny og effektivisere det, der i koldkrigstider var kendt som de eurostrategiske våben. Det drejer sig først og fremmest om kort- og mellemdistancevåben med atomkapacitet, ligesom der igen gennemføres forsøg med fremføringsmidler for strategiske kernevåben.

Men Ukraine-krisen har afsløret mere end det, og det gør NATOs opgave særlig svær. For i opgøret om Krim tog Rusland en palet af virkemidler i brug - fra propaganda over magtdiplomati, økonomisk krigsførelse og undergravende virksomhed til infiltration og direkte magtanvendelse. Moskva viste, at det har evnen til af afbalancere brugen af de enkelte 'våben' og til at skrue op og ned for hvert af dem efter situationens behov. Det kræver stram styring og et stærkt hierarkisk system at sikre, at de enkelte virkemidler sættes ind i de rette doser på de rigtige tidspunkter, og Krim-mellemspillet viste, at Moskva har de evner.

En sideeffekt af stram styring og udpræget hierarkisk opbyggede systemer er, at Vladimir Putin har vanskeligt ved at argumentere, at han ikke har været med i beslutningsprocesserne hele vejen. Han kan ikke påstå uvidenhed eller fralægge sig ansvar. Det kan få betydning, når det en gang 
er klarlagt, hvad der virkelig skete, da et rutefly fra Malaysias luftfartsselskab blev skudt ned over det østlige Ukraine med tab af 298 uskyldige og fuldstændig uinvolverede menneskeliv til følge. Vesten mistænker Rusland for meddelagtighed, Moskva afviser ethvert ansvar.

Det store billede er omtrent sådan her:

Rusland har vist, at det har viljen til at dominere sine nærområder, om nødvendigt med militær magt. Rusland har samtidig vist, at det har de militære evner til at forfølge sådan en hensigt og, at det kan koordinere og styre indsatsen af mangfoldige redskaber på en gang for at nå et mål. Og Rusland har signaleret, at det ikke længere ser sin egen fremtid som en del af det euroatlantiske projekt eller det Helsinki-europæiske projekt, men orienterer sig mod øst og syd i sit eget euro-asiatiske projekt.

\section{En ny strategi}

Det er den nye situation, NATO og EU må tilpasse deres strategier efter, samtidig med at de må indse, at Rusland er en militær og økonomisk størrelse, som de ikke kan komme uden om at have relationer til i fremtiden. Det sidste er måske det mindst vanskelige, fordi NATO og EU allerede i dag er afhængig i større eller mindre grad af Rusland - NATO og USA i en række militære og sikkerhedspolitiske sammenhænge, EU i en række økonomiske og handelsmæssige sammenhænge.

Det første - at udvikle en tilpasset strategi - er langt vanskeligere. Rusland har vist, at det har evnen til at føre hybrid-krige, altså krige der udkæmpes med en hel vifte af militære og civile, diplomatiske og økonomiske, propagandistiske og efterretningsmæssige, åbne og skjulte våben, som en nøje koordineret og afstemt, og som alle trækker mod det ønskede politiske mål.

NATO står tilsvarende overfor en mangfoldighed af trusler - 'ambigous threats' som er en enorm udfordring for enhver organisation, men især for en koalition eller alliance som NATO. For netop mangfoldigheden af truslerne gør, at hvert medlem af alliancen kan lægge sit eget fokus, kan lave sin egen vægtning af, hvilke trusler der er vigtigere end andre - og derfor også komme op med sit eget svar på spørgsmålet om, hvor tyngden i alliancens modsvar skal lægges. For NATO betyder det, at 28 medlemslande kan give 28 forskellige svar på, hvad reaktionen skal være for at skabe den ønskede effekt i Moskva.

Hvad der gælder NATO, gælder i lige så høj grad EU - måske højere. For mens NATO fokuserer på den militære trussel og søger militære og sikkerhedspolitiske svar, er det EU, der skal stå for den politisk-diplomatiske og ikke mindst den økonomiske modstrategi. Problemet er, at EU siden den kolde krigs afslutning har været det instrument, der har ført tanken om størst mulig gensidig økonomisk afhængighed som et europæisk fredsprojekt ud i livet. Og nu står EU så i den situation, dels at medlemslandene skal overtales til økonomiske sanktioner mod Rusland, som rammer dem selv mindst lige så hårdt, som de rammer russerne, dels at $\mathrm{EU}$ må indse, at Rusland måske slet ikke er med på logikken i gensidig afhængighed. EU og Rusland opstiller ikke nødvendigvis det samme regnestykke, når det handler om nationale interesser. Det EU måske ser som en strafpris, som Rusland må betale, ser Moskva måske som en acceptabel investering i det projekt, Rusland er gang med.

\section{EU's og NATOs dilemma}

For EU melder der sig to overordnede spørgsmål. Det ene er, at hvis EU's økonomiske og diplomatiske instrumenter ikke har den ønskede effekt i Moskva, hvad skal EU så gøre? Det andet er, at hvis EU's tilbud om samarbejds- og associeringsaftaler til lande, der ikke kan optages som medlemmer, viser sig at have en konfliktudløsende eller konfliktoptrappende effekt, som det er tilfældet i Ukraine, hvad kan EU så tilbyde kandidatlande, som af den ene eller anden 
grund ikke kan samle konsensus blandt EUlandene om et medlemskab?

EU's dilemma spejles i NATO, hvad det sidste angår. Hvilke sikkerhedsgarantier kan alliancen tilbyde lande, der ikke kan optages som medlemmer og altså få artikel fem-garantierne i Washington-traktaten, men som NATO godt vil have som partnerskabslande, og som netop på grund af en partnerskabsstatus bliver sårbare over for russiske intimideringsforsøg? Spurgt mere direkte: i lyset af Ukraine-erfaringerne, hvad er Partnerskab for Fred-programmet så værd, og hvad er dets indhold?

Men NATOs hovedpine er større end som så. For et Rusland, der er ved at rive Helsinki-slutakten i stykker, kan kun opfattes som en trussel i lande som de baltiske, Polen og Rumænien. Alle lande, der er med i NATO og omfattet af artikel fem. NATO må finde en ny balance mellem at være global spiller med hurtige indsatsstyrker af Afghanistantypen og alliancespiller med regionale forsvarsstyrker til paragraf fem-indsatser. Det er også balancen mellem troværdig afskrækkelse på globalt plan og troværdige sikkerhedsgarantier på alliance-territorium.

Den akademiske leder af Forbundsakademiet for Sikkerhedspolitik i Berlin, KarlHeinz Kamp, formulerer i en forskningsrapport fra NATOs Forsvarsakademi i Rom fem udfordringer til NATO, som udspringer af Ukraine-krisen:

- NATO må redefinere sin forbindelse med Rusland på langt sigt og afgøre med sig selv om alliancen vil se Rusland som en strategisk partner, som blot en partner blandt mange, som en nabo eller som en modstander eller ligefrem en fjende.
- NATO må finde ud af, hvad alliancen vil med sin udvidelsespolitik.

- NATO må afklare, hvad følgerne er af USA omorientering mod Stillehavet og Asien.

- NATO må tilpasse sine partnerskaber til en tid efter Afghanistan og ISAF-koalitionen der.

- NATO må afklare, hvad alliancens rolle skal være i Mellemøsten.

Alt det, mener Kamp, må nytænkes og omtænkes, og netop det han kalder Ruslands neoimperiale handlinger, tvinger de her spørgsmål frem, som alliancen hidtil er veget udenom eller har undladt at diskutere med den fornødne energi og alvor. Han kondenserer NATOs problemer til den dobbelt udfordring at på den ene side sikre medlemsstaternes territoriale integritet mod udefra kommende farer og på den anden side sikre alliancen som en af de vigtige producenter af stabilitet $i$ det internationale samfund.

NATO-topmødet i Newport i Wales i september blev på forhånd beskrevet som skelsættende, fordi det er det topmøde, der afstikker kursen for alliancen fra krigsindsatsen i Afghanistan til tiden efter Afghanistan. Det skulle have været en alliancedrevet nøgtern diskussion om NATOs fremtidige rolle og de kapaciteter, alliancen får brug for til den rolle.

I stedet er dagsordenen sat af Ukraine, eller rettere af Ruslands opførsel i og omkring Ukraine.

NATOs umiddelbare udfordring er at vise, at alliancen har generobret initiativet og sætter sin egen dagsorden. 